\title{
Hubungan Caring Perawat Dengan Kepuasan Pasien Rawat Inap Di Rumah Sakit Rumah Harapan Bunda Kota Batam
}

\author{
Nahrul Hayat ${ }^{1}$, Asfri Sri Rahmadeni ${ }^{2}$, Marzuki ${ }^{3}$ \\ ${ }^{1}$ Dosen Prodi DIII Keperawatan'Institut Kesehatan Mitra Bunda \\ 2 Dosen Prodi DIII Keperawatan'Institut Kesehatan Mitra Bunda \\ ${ }^{3}$ Mahasiswa Prodi Sarjana Keperawatan'Institut Kesehatan Mitra Bunda
}

\section{INFORMASI ABSTRACT}

Korespondensi: aniasfri@mail.com

Keywords:

Caring of Nurse, Patient Satisfaction
Caring nurses are very important in meeting patient satisfaction, this is one indicator of the quality of service in a hospital. Nurses are people who become one of the keys in meeting patient satisfaction. Therefore, caring nurse behavior can have an effect on quality service to patients. Some studies conducted in Indonesia show that caring is still lacking for patients in hospitals as much as 50\% show poor caring. Patient satisfaction is influenced by caring nurses in serving patients in hospitals. The purpose of this study was to analyze the relationship between caring nurses and patient satisfaction in the inpatient room. This study is a cross sectional analytic study and purposive sampling technique with a sample of 67 patients, collecting data using a questionnaire. The Chi-Square test results showed a significant relationship between caring nurses and patient satisfaction in the inpatient room with a $p$ value of 0,045 $(\alpha=0,05)$. Nurse caring attitude greatly affects patient satisfaction so it is expected that nurses or other health workers can be more sensitive, be responsive and respond well to patient complaints and show sincere care in helping patients recover. 


\section{PENDAHULUAN}

Rumah sakit memiliki peran yang sangat strategis dalam upaya mempercepat peningkatan derajat kesehatan masyarakat. Paradigma baru pelayanan kesehatan mengharuskan rumah sakit memberikan pelayanan berkualitas sesuai kebutuhan dan keinginan pasien dengan tetap mengacu pada kode etik profesi. Dalam perkembangan teknologi yang pesat dan persaingan yang semakin ketat, maka rumah sakit dituntut untuk terus melakukan peningkatan kualitas pelayanannya(Keputusan Menteri Kesehatan Republik Indonesia, t.t.).

Pelayanan kesehatan di indonesia yang diberikan oleh rumah sakit terus berkembang dan selalu memberikan perubahan yang cepat karena arus era globalisasi yang sedang kita hadapi dibidang kesehatan. Hal tersebut juga berdampak dan berpengaruh penting dalam bidang kesehatan. Petugas Kesehatan terutama perawat adalah kunci utama dalam keberhasilan pencapaian tujuan pembangunan kesehatan. Hal terpenting agar pasien tetap menggunakan jasa rumah sakit tersebut adalah tergantung pada bagaimana pasien tersebut merasa puas dan senang mendapatkan pelayanan (Purwoastuti \& Walyani, 2019).

Fokus utama dari keperawatan adalah faktor-faktor caring yang bersumber dari perspektif humanistic yang dikombinasikan dengan dasar pengetahuan ilmiah. Watson kemudian mengembangkan sepuluh faktor caring tersebut untuk membantu kebutuhan tertentu dari pasien dengan tujuan terwujudnya integritas fungsional secara utuh dengan terpenuhinya kebutuhan biofisik, psikososial dan kebutuhan interpersonal.Perilaku caring sangat diperlukan oleh seseorang dalam pember pelayanan, karena hubungan antara pemberi pelayanan kesehatan dengan pasien merupakan faktor yang mempengaruhi proses kepuasan dan kesembuhan pasien tersebut (Watson, 2009)

Perilaku caring sangat penting karna dapat menigkatkan mutu pelayanan, namun dibeberapa rumah sakit berdasarkan penelitian masih ditemukannya perilaku caring yang kurang baik. RSUP Prof. Dr. R. D. Kandou Manado didapatkan perilaku caring perawat kurang baik hasil $26,7 \%$ (Gaghiwu dkk., 2013). RSUD Dr. H. Soewondo kendal mendapatkan 29,6\% perawat kurang caring terhadap pasien(Martiningtyas dkk., 2013). RSU dr. H. Koesnadi Bondowoso menunjukan separuh perawat 50\% berperilaku kurang caring(Prabowo dkk., 2014). Bila dilihat dari ketiga Rumah Sakit tersebut maka tingkat perilaku caring yang dimiliki oleh seorang perawat masih rendah.

Perilaku caring perawat yang rendah dapat dinilai dari 10 faktor karatif teori dasar Watson. Berdasarkan teori yang dilapangan masih ditemukan adanya pasien merasa tidak puas akan pertanyaan yang diajukan terhadap perawat, kurang rasa peduli/peka terhadap keluhan pasien serta terkadang masih ada perawat ketus/jutek. Maka dengan demikian kesan seperti ini secara tidak langsung juga dapat menimbulkan persepsi buruk dari pasien tentang pelayanan keperawatan yang diberikan (Rinna, 2016).

Berbagai hal yang ditemukan dilapanggan maka hal ini dapat mempengaruhi kepuasan pasien dalam menerima suatu pelayanan. Faktor-faktor yang mempengaruhi kepuasan pengguna jasa pelayanan kesehatan yaitu, pemahaman pengguna jasa tentang jenis pelayanan yang akan diterimanya. Komunikasi memegang peranan yang penting karena pelayanan kesehatan merupakan high personel contact, sikap peduli yang ditunjukkan oleh petugas kesehatan, biaya (cost), penampilan fisik (kerapian) petugas (Muninjaya, 2004).

Studi pendahuluan yang dilakukan di Rumah Sakit Graha Hermine dari 15 orang perawat 11 diantaranya mengatakan perilaku caring tidak dilakukan secara maksimal dikarenakan jika mengaplikasikan perilaku caring maka waktu yang dibutuhkan akan menjadi lama dalam melakukan suatu tindakan keperawatan seperti contohnya mereka tidak melakukan pra interaksi dengan lengkap, tahap kerja yang di kerjakan dengan tergesa-gesa sedangkan 4 orang menjawab perilaku caring dapat diaplikasikan tanpa mengganggu waktu melakukan tindakan keperawatan. Sedangkan untuk kepuasan pasien berdasaran wawancara dengan 5 orang pasien didapatkan pasien mengatakan tidak puas, kepedulian perawat dalam memberikan pelayanan sangat rendah terutama malam hari karena perawat tidak memperhatikan kebutuhan pasien.

Jumlah perawat tahun 2017 perawat yang terdapat di Rumah Sakit Harapan Bunda berjumlah 123 orang yang tersebar diruang Rawat Inap, Poli, IGD, ICU, Kebidanan. Menurut data yang didapatkan jumlah kunjungan pasien di Rumah Sakit Harapan Bundadari bulan Januari sampai Desember tahun 2017 berjumlah 10383 orang yang tersebar diruang rawat inap, artinya rata-rata jumlah kunjungan sebanyak 903 perbulan (Rumah Sakit Harapan Bunda "Profil Rumah Sakit Harapan Bunda" Batam 2017, t.t.) 
Berdasarkan survey awal yang dilakukan di Rumah Sakit Harapan Bunda caring perawat masih belum maksimal dilakukan misalnya dalam proses orientasi dengan pasien masih kurang seperti tidak memperkenalkan diri dan menjelaskan tindakan yang akan dilakukan terhadap pasien tersebut. Kebutuhan yang dibutuhkan oleh pasien diantaranya pelayanan yang cepat dan responssive, kejelasan pemberian informasi, keramahan, kesopanan dan keadilan, pelaksaan prosedur yang kompeten. Kebutuhan tersebut merupakan bagian dari proses caring perawat dan hanya ada beberapa kebutuhan yang telah dilakukan seperti pelaksaan posedur yang kompeten, pemberian motivasi sedangkan elemen lainya belum terlaksana.

Penelitian yang dilakukan di Rawat Inap Rumah Sakit dari 64 responden menunjukkan bahwa $81,3 \%$ responden mempunyai persepsi bahwa perawat mempunyai perilaku caring yang baik dan menunjukkan kepuasan terhadap pelayanan keperawatan. Hasil uji fisher menunjukkan $\mathrm{p}=$ 0,000, Namun masih terdapat 6,2\% yang kurang puas dengan perilaku caring perawat(Saleh \& Sjattar, t.t.). Rawat Inap RSUD Klungkung didapatkan sebanyak $61(48 \%)$ responden berperilaku tidak caring dan yang berperilaku caring sebanyak 65(52\%) responden. Sedangkan distribusi frekuensi responden berdasarkan kepuasan pasien didapatkan yang merasa tidak puas 74 (59\%) responden sebanyak $52(41 \%)$ responden Puas. Nilai $p$ value sebesar $0,001(\mathrm{p}<0,05)($ Darmawan, 2016). Rawat inap Ruangan Kelas III Rumah Sakit Immanuel dari 61 responden menunjukkan bahwa sebagian responden mengatakan perilaku caring perawat tinggi yaitu $44(72,1 \%)$, tingkat kepuasan yang dirasakan oleh responden adalah puas dengan 55 responden $(90,2 \%)$ , nilai $p$-value sebesar 0.026(Hutapea dkk., 2014).

Berdasarkan hal tersebut danya hubungan yang signiikan antara caring dengan kepuasan pasien, namun angka kepuasan yang bervariasi tetapi tidak melebihi angka standar pelayanan, dimana angka kepuasan pasien masih rendah dari 90\%( keputusan menteri kesehatan republik indonesia, t.t.)

Rendahnya angka kepuasan tersebut maka peneliti akan melakukan penelitian hubungan caring dengan kepuasan pasien rawat inap di rumah sakit, sehingga nantinya dapat meningkatt mutu pelayanan baik dari perawat itu sendiri maupun dari rumah sakitnya.

\section{METODE}

Penelitian ini termasukjenis penelitian analitik dengan desain atau rancangan cross sectional. Pendekatan ini di gunakan untuk melihat hubungan perilaku caring perawat dengan kepuasan pasien diruang rawat inap Rumah Sakit Harapan Bunda Kota Batam 2018.

Pengambilan sampel dalam penelitian ini dengan kriteria inklusi pasien yan bersedia menjadi responden, di rawat di RS, pasien yang BPJS dan Non BPJS serta yang mamu berkomunikasi dengan baik, untuk kriteria ekslusi Pasien diruangan ICU/ khusus, Pasien anak/ yang tidak bisa membaca dan menulis. Teknik pengambilan sampel dalam penelitian ini dengan menggunakan non probability sampling dengan teknik purposive sampling yaitu pengambilan dengan pertimbangan tertentu sesuai dengan tujuan yang dikehendaki. Besar sampel penelitian berjumlah 67 Pasien di Instalasi Rawat Inap Rumah Sakit Harapan Bunda. Sebelum penelitian pasien akan diberi informed consent menyatakan persetujuannya dan data yang diberikan akan dijamin kerahasiaannya. Penelitian dilakukan pada bulan Oktober 2018.

Variable independen pada penelitian ini adalah Caring Perawat dan variable independen kepuasan pasien. Instrument yang digunakan pada penelitian berupa kuesioner dimana variabel bebas caring perawat kuesioner terdiri dari 42 pernyataan, sedangkan instrumen kepuasan pasien kuesioner terdiri dari 15 pernyataan. Analisa data yang digunakan Univariat Untuk menilai caring perawat ataupun kepuasan pasien dengan hasil ukur memakai median dan analisa bivariat menggunakan Uji statistik Kai Kuadrat.

\section{HASIL}

Tabel 4.1 Distribusi Frekuensi Data Demografis

\begin{tabular}{lcc}
\hline \multicolumn{1}{c}{ Usia } & n & \% \\
\hline Remaja Akhir (17-25 Tahun) & 25 & 37,3 \\
\hline Dewasa Awal (26-35 Tahun) & 23 & 34,3 \\
\hline Dewasa Akhir (36-45 Tahun) & 14 & 20,9 \\
\hline Lansia Awal (46-55 Tahun) & 5 & 7,5 \\
\hline Jenis Kelamin & & \\
\hline Laki-laki & 23 & 34,3 \\
\hline Perempuan & 44 & 65,7 \\
\hline
\end{tabular}

Berdasarkan tabel 4.1 menunjukkan bahwa sebagian besar usia pada penelitian ini yaitu usia Remaja Akhir (17-25 tahun ) sebanyak 25 pasien (37,3\%). Untuk jenis kelamin pasien sebagian besar perempuan dengan jumlah 44 pasien (65,7\%). 
Tabel 4.2 Distribusi Frekuensi Berdasarkan Caring Perawat

\begin{tabular}{lcc}
\hline Caring Perawat & Frekuensi (n) & $\begin{array}{c}\text { Persentase } \\
\text { (\%) }\end{array}$ \\
\hline Caring & 47 & 70,1 \\
\hline Tidak Caring & 20 & 29,9 \\
\hline Jumlah & 67 & 100 \\
\hline
\end{tabular}

Berdasarkan tabel 4.2 menunjukkan bahwa sebagian besar perawat caring dengan jumlah 47 perawat $(70,1 \%)$.

Tabel 4.3 Distribusi Frekuensi Berdasarkan Kepuasan Pasien

\begin{tabular}{lcc}
\hline Kepuasan Pasien & Frekuensi (n) & $\begin{array}{c}\text { Persentase } \\
\text { (\%) }\end{array}$ \\
\hline Puas & 36 & 53,7 \\
\hline Tidak Puas & 31 & 46,3 \\
\hline Jumlah & 67 & 100 \\
\hline
\end{tabular}

Berdasarkan tabel 4.3 menunjukkan bahwa sebagian besar pasien yang puas berjumlah 36 pasien $(53,7 \%)$.

Tabel 4.4 Hubungan Caring Perawat Dengan Kepuasan Pasien di Ruang Rawat Inap Rumah Sakit Harapan Bunda

\begin{tabular}{|c|c|c|c|c|c|}
\hline \multirow{3}{*}{$\begin{array}{l}\text { Caring } \\
\text { Perawat }\end{array}$} & \multicolumn{4}{|c|}{ Kepuasan Pasien } & \multirow{3}{*}{$\begin{array}{c}\mathbf{P} \\
\text { Value }\end{array}$} \\
\hline & \multicolumn{2}{|c|}{ Puas } & \multicolumn{2}{|c|}{$\begin{array}{c}\text { Tidak } \\
\text { Puas } \\
\end{array}$} & \\
\hline & $\mathbf{N}$ & $\%$ & $\mathbf{N}$ & $\%$ & \\
\hline Caring & 29 & 61,7 & 18 & 38,3 & \multirow{3}{*}{0,045} \\
\hline Tidak Caring & 7 & 35,0 & 13 & 65,0 & \\
\hline Jumlah & 36 & 53,7 & 31 & 46,3 & \\
\hline
\end{tabular}

Berdasarkan Tabel 4.4 menunjukkan bahwa dari 67 pasien, 47 perawat yang caring dengan pasien yang puas sebanyak $29(61,7 \%)$, dan dari 20 yang tidak caring terdapat $13(65,0 \%)$ pasien yang tidak puas.

\section{PEMBAHASAN}

\section{Caring perawat di ruang rawat inap Rumah Sakit} Harapan Bunda

Hasil penelitian di Rumah Sakit Harapan Bunda bahwa dari 67 pasien sebagian besar dengan perawat yang caring sebanyak 47 perawat $(70,1 \%)$.

Hasil penelitian Di Ruang Perawatan Teratai Rumah Sakit Umum Pusat Fatmawati, menunjukkan data bahwa $51(64,2 \%)$ responden menyatakan caring baik(Kalsum, 2016). Hasil penelitian Rawat Inap Di RSUD Klungkung menunjukkan bahwa hampir separuh perawat yang bertugas dinilai caring baik sebanyak 65 responden (52\%)(Darmawan, 2016).

Caring merupakan hal utama dalam praktik keperawatan, karena caring merupakan alat utama untuk berkomunikasi dan obat yang utama dalam tindakan keperawatan sebelum farmakologi dilakukan. Caring yang baik akan menunjukan adanya rasa kepedulian yang besar terhadap pasien(Sudarta, 2015).

Dampak positif caring bagi pasien diantaranya kesembuhan pasien meningkat, usia lebih panjang, pasien merasa aman dan nyaman selama dirawat, pasien akan memiliki rasa percaya yang tinggi kepada perawat dan pasien akan terhindar dari perasaan asing terhadap perawat. Dampak negatif bagi pasien apabila perawat tidak berperilaku caring adalah pasien akan merasa takut, khawatir, hilang kontrol, dan pasien akan merasa terasing, proses kesembuhan pasien akan menjadi lebih sulit, dan hubungan interpersonal perawat pasien tidak terjalin(Watson, 2009).

Peneliti menarik kesimpulan caring sangat penting untuk menampilkan asuhan keperawatan mandiri yang dapat dioptimalkan untuk memberikan rasa nyaman bagi pasien sehingga ketenangan emosi dan jiwa pasien dapat terwujud yang berdampak baik bagi pemulihan kesehatan pasien. Dampak positif caring bagi perawat mereka akan merasakan kepuasan dalam dirinya karena mampu melaksanakan tindakan sesuai tujuan yang ingin dicapai, dan adanya perasaan ikhlas membantu pasien.

\section{Kepuasan Pasien di Ruang Rawat Inap Rumah Sakit Harapan Bunda}

Hasil penelitian di Rumah Sakit Harapan Bunda bahwa dari 67 pasien menunjukkan bahwa sebagian besar pasien menyatakan puas dengan jumlah 36 pasien $(53,7 \%)$. Hasil penelitian Di Ruang Perawatan Teratai Rumah Sakit Umum Pusat Fatmawati, hasil penelitian menunjukkan bahwa sebanyak 51 responden (63\%) menyatakan puas(Kalsum, 2016). Hasil penelitian Di Ruang Rawat Inap Private Care Centre RSUP DR Wahidin Sudirousodo Makasar menunjukkan sebanyak 30 responden (75\%) dengan kepuasan pasien yang puas(Ilkafah, 2017).

Kepuasan merupakan ungkapan perasan senang atau kekecewaan seseorang yang muncul akibat telah melakukan pekerjaan sesuai dengan tujuan yang diharapkan(Kotler, 1991). Peneliti menarik kesimpulan pasien akan merasa puas apabila pelayanan kesehatan yang diperolehnya sama atau 
melebihi harapanya.

\section{Hubungan Caring Perawat Dengan Kepuasan Pasien di Ruang Rawat Inap Rumah Sakit Harapan Bunda}

Hasil penelitian di Rumah Sakit Harapan Bunda, di dapatkan hasil dari 67 pasien, 47 perawat yang caring dengan pasien yang puas sebanyak $29(61,7 \%)$, dan dari 20 yang tidak caring terdapat $13(65,0 \%)$ pasien yang tidak puas.

Hal ini sesuai dengan uji statistik chi-square diperoleh nilai $\mathrm{P}$ - value sebesar $0,045<0,05$. Hal ini berarti ada hubungan yang signifikan antara caring perawat dengan kepuasan pasien rawat inap di Rumah Sakit Harapan Bunda kota Batam tahun 2018.

Hasil penelitian Rawat Inap Rumah Sakit RSUD Baubau menyebutkan terdapat hubungan antara perilaku caring perawat yang baik dan menunjukkan kepuasan terhadap pelayanan keperawatan dengan menggunakan uji statistik menunjukkan nilai $\mathrm{p}$ $=0,000<\alpha=0,05\left(\mathrm{H}_{0}\right.$ ditolak)(Saleh \& Sjattar, t.t.). Penelitian Di RSUD DR. Rasidin Padang menunjukkan terdapat hubungan yang bermakna antara perilaku caring perawat dengan tingkat kepuasan pada pasien BPJS dengan $p$ value $=0,002$ (Mailani $\&$ Fitri, 2017). Penelitian Di Ruang Perawatan Teratai Rumah Sakit Umum Pusat Fatmawati menyebutkan terdapat hubungan antara respectful deference dengan kepuasan pasien di ruang perawatan teratai dengan $p$ value $=0,008<0,05$ (Kalsum, 2016).

Pernyataan tersebut sesuai dengan teori yang mengatakan bahwa caring merupakan praktik keperawatan dimana perawat membantu klien pulih dari sakitnya. Kehadiran, kontak mata, bahasa tubuh, nada suara, sikap mau mendengarkan serta memiliki sikap positif dan bersemangat yang dilakukan perawat kepada klien akan membentuk suasana keterbukaan dan saling mengerti, serta perlakuan yang ramah dan cekatan ketika melaksanakan prosedur keperawatan akan memberikan rasa aman pada klien (Potter \& Perry, 2009)

Semakin baik perilaku caring perawat dalam memberikan pelayanan asuhan keperawatan, pasien atau keluarga semakin senang dalam menerima pelayanan sehingga hubungan terapeutik perawatklien semakin terbina. Dimana disini diharapkan perawat lebeih memperhatikan pola komunikasi, lebih peka terhadap keluhan dan cepat tanggap terhadap hal yang terjadi pada pasien dengan menunjukan rasa yang ikhlas, Maka dengan demikian mutu pelayanan rawat inap rumah sakit akan jauh lebih baik serta dapat mempercepat masa penyembuhan pasien.

\section{KESIMPULAN}

Hasil penelitian disimpulkan 47(70,1\%) pasien menyatakan parawat berada pada kategori carring. Tingkat kepuasan pasien berada pada kategori puas 36 (53,\%). Maka Adanya hubungan yang signifikan antara caring perawat dengan kepuasan pasien di ruang rawat inap Rumah Sakit dengan uji statistik chi-square diperoleh nilai $p$ value sebesar $0.045<0.05$.

\section{DAFTAR PUSTAKA}

Darmawan, A. K. N. (2016). Hubungan Perilaku Caring Perawat Terhadap Tingkat Kepuasan Pasien Rawat Inap Di RSUD Klungkung. Jurnal Dunia Kesehatan, 5(1), 76396.

Gaghiwu, L., Ismanto, A. Y., \& Babakal, A. (2013). Hubungan Perilaku Caring Perawat Dengan Stres Hospitalisasi Pada Anak Usia Toddler Di Irina E Blu Rsup Prof. Dr. RD Kandou Manado. Jurnal Keperawatan, 1(1).

Hutapea, K. A., Dedi, B., \& Elias, Y. (2014). Hubungan Perilaku Caring Perawat Dengan Tingkat Kepuasan Pasien yang Dirawat di Ruangan Kelas III Rumah Sakit Immanuel Bandung. 8, 10. Ilkafah, A. (2017). Perilaku Caring Perawat dengan Kepuasan Pasien di Ruang Rawat Inap Private Care Centre RSUP Dr Wahidin Sudirohusodo Makassar. Jurnal Keperawatan, 8(2), 138-146. https://doi.org/10.22219/jk.v8i2 Juli.4034

Kalsum, U. (2016). Hubungan Perilaku Caring Perawat dengan Kepuasan Pasien di Ruang Perawatan Teratai Rumah Sakit Umum Pusat Fatmawati tahun 2016.

Keputusan Menteri Kesehatan Republik Indonesia. (t.t.). 55.

Kotler, P. (1991). Marketing management: Analysis, planning, implementation, and control (7th ed., 2. print). Prentice Hall.

Mailani, F., \& Fitri, N. (2017). Hubungan perilaku caring perawat dengan tingkat kepuasan pasien bpjs di ruang rawat inap rsud dr. Rasidin padang. Jurnal Endurance: Kajian Ilmiah Problema Kesehatan, 2(2), 203-208.

Martiningtyas, L., Sukesi, N., \& Kusuma, M. A. B. (2013). Hubungan Caring Perawat Pelaksana Dengan Kepuasan Pasien Di Ruang Rawat Inap RSUD Dr.H. Soewondo Kendal. Jurnal Ilmu Keperawatan dan Kebidanan, 1(4). 
Muninjaya, A. A. G. (2004). Manajemen Kesehatan... Ed.2. EGC.

Potter, P. A., \& Perry, A. G. (2009). Fundamentals of Nursing, Fundamental Keperawatan, Edisi 7 Buku 1. Salemba Medika, Jakarta.

Prabowo, B. S., Ardiana, A., \& Wijaya, D. (2014). Hubungan Tingkat Kognitif Perawat tentang Caring dengan Aplikasi Praktek Caring di Ruang Rawat Inap RSU dr. H. Koesnadi Bondowoso (The Correlation between Nurses Cognitive Level on Caring with Caring Practice Application in the Inpatient Unit RSU dr. H. K. Pustaka Kesehatan, 2(1), 148-153.

Purwoastuti, T. E., \& Walyani, E. S. (2019). Perilaku \& Softskills Kesehatan: Panduan untuk tenaga Kesehatan (Perawat dan Bidan). http://r2 kn.litbang.kemkes.go.id:8080/ handle/123456789/64828

Rinna, E. (2016). Hubungan tingkat emotional in囚ligence dengan perilaku caring perawat pelaksana di ruang rawat inap rsud dr. Rasidin padang tahun 2016 [PhD Thesis]. Universitas Andalas.

Rumah Sakit Harapan Bunda "Profil Rumah Sakit Harapan Bunda" Batam 2017. (t.t.).

Saleh, A., \& Sjattar, E. L. (t.t.). Hubungan Perilaku Caring Perawat Dengan Tingkat Kepuasan Pasien Rawat Inap Rumah Sakit. 10.

Sudarta, I. W. (2015). Managemen keperawatan: Penerapan teori modal dalam pelayanan keperawatan. Gosyen Publishing/2015.

Watson, J. (2009). Assessing and measuring caring in nursing and health sciences (2nd ed). Springer Pub. Co. 